DOI: 10.20472/IAC.2019.048.046

PITAN SANPAKDEE

Rajamangala University of Technology Suvarnabhumi Thailand., Thailand

\title{
COST AND RETURN ON INVESTMENT FROM LAYING DUCKS FARMING OF THE FARMERS IN BANGPLAMA DISTRICT, SUPHANBURI PROVINCE, THAILAND
}

\begin{abstract}
:
The purposes of this research study were 1 ) to study cost and return on investment from laying ducks Farming of the Farmers in Bang pla ma district, Suphanburi province 2) to analyze cost and return on investment from laying ducks Farming. The sample of 16 farmers drawn by the method of purposive sampling. The study was conducted by collecting data and analyzing the data obtained by in-depth interviews, the tool was interview questions. Quantitative data were analyzed using the following cost, profit, Net profit to cost ratio, Net profit to sales ratio, Return on investment and break-even point.

Results of cost and return indicated that total average cost was 1,609.28 baht per duck, while average net profit was 325.68 baht per duck. Net profit to cost ratio was $20.24 \%$, while net profit to sales ratio was $6.83 \%$. Return on investment (ROI) was $19.97 \%$ and break-even point was 152 eggs per duck. Cost of laying ducks comprised 3 important costs which were $8.17 \%$ of raw material cost, $4.17 \%$ of labor cost and $87.66 \%$ of overhead cost.
\end{abstract}

\section{Keywords:}

Cost, Return, Ratio, laying ducks, Duck raising

JEL Classification: D24, M19, Q19 


\section{INTRODUCTION}

Ducks are one of the most economic animals that are commonly raised in almost every province with the purpose of consuming meat and eggs. Although the domestic duck consumption is still lower than other types of meat consumption which the market demand is still rising depending on the increasing in population (Chiraphon, 2014). According the report of statistical data on egg-laying ducks in Thailand in 2018, it was found that there were 80,593 egg-fed farmers and $8,691,473$ of them.

Table 1: the province with the highest number of 5 egg ducks in 2018.

\begin{tabular}{lll}
\hline Province & Number & (Percentage) \\
\hline Suphanburi & $1,621,536$ & 18.66 \\
\hline Ang Thong & $1,250,007$ & 14.38 \\
\hline Nakhon Pathom & 950,435 & 10.94 \\
\hline Songkhla & 413,444 & 7.76 \\
\hline Chainat & 274,484 & 3.16 \\
\hline
\end{tabular}

Source: Information and Communication Technology Center, Department of Livestock Development, 2018

Suphanburi province has a large amount of livestock production, including chicken, duck, swine, and cattle. For Suphanburi Province, the total number is about 7,008,781 which 1,621,536 are duck eggs that Bang Pla Ma district will have the most duck eggs and considered as an economic animal of SuphanBuri (Suphan Buri Provincial Livestock Office, 2018). In the past, there will be the raising of duck eggs by using natural food, but at the present time, farmers are unable to bear the higher price of raw materials and causing higher labor costs (Warat Somsom, 2561).

From these problems of the farmers, the researcher is interested in studying and analyzing the cost and return on investment of the duck egg farmers of Bang Pla Ma District, Suphanburi Province, to bring the results from the study as information and guidelines for farmers or stakeholders to consider in making investment decisions for raising duck eggs.

\section{Research Objectives}

1. To study general information of egg duck farmers at Bang Pla Ma, Suphanburi Province.

2. To analyze the cost and financial return of egg duck farmers at Bang Pla Ma, Suphanburi Province

\section{Scope of Research}

Studying the general information and financial cost and return analysis of egg duck farmers at Bang Pla Ma, Suphanburi Province. The population used in the research is egg duck farmers at Bang Pla Ma, SuphanBuri Province, 16 persons, during the period from August 2018 to December 2018. 


\section{Literature Review}

\section{Concepts and theories of cost analysis}

Cost means having relevance to those entrepreneurs for both business and non-business, which may be the business of producing products, selling products or providing services. In general, the type of cost or cost classification depends on the production of the product. Sales of goods are the costs incurred in buying and selling products. Although service has cost related to service (Maher, Sticky \& Well, 2001), according to the concept of Jones, Werner, Terrell P. and Terrell L. (2000) and the idea that cost is the amount or obligation that must be paid in the future. Acquiring assets or services with the amount of money or obligations will benefit the future or may take advantage of the money already paid, such as buying machinery, buying goods, paying wages, etc.

Classification of cost according to product components can be classified into 3 types as follows:

1. Materials means raw materials that are used as important components in production which can be divided into 2 types: direct raw materials and indirect raw materials.

2. Labor costs means compensation (wages) paid to employees or workers related to the production of goods whether in the form of salary, hourly compensation, piece or in other forms such as overtime, bonus, reward, etc. Labor costs can be divided into 2 types, namely direct labor and indirect labor costs.

3. Production costs (Manufacturing Overhead), also known as expenses factory overhead / factory burden, means the costs incurred in all production in a factory that cannot be directly accounted for as a direct material which are indirect raw materials, indirect labor costs, utilities costs related to production include water - electricity, factories, rent, insurance premiums, property tax, factory depreciation, machinery depreciation, and miscellaneous expenses in the factory. That can be divided into 2 types which are variable costs and fixed costs.

\section{Theory of return and the analysis of return on investment}

Return on investment means what investors wish to get from investing in securities or real estate (Sukjai Satpanya, 2011). Analysis of return on investment is a purpose to analyze the projects that are prepared in worth the investment. In general, the analysis is divided into 2 types: analysis methods with discounted methods and analytical methods without discounting. (Undiscounted Approach) (Piyachat Techasub, 2014). This research will study only the analytical methods without discounting (Undiscounted Approach) that can use analytical methods in many ways. Popular methods include break-even analysis, net profit margin per cost, net profit margin per sales and return on investment (Sasiwimol Miampon, 2007).

\section{Research Methodology}

This research is a qualitative research which data were collected by in-depth interview by using the interview question form as a tool to collect data, consisting of raw material costs, labor costs, production costs and average income per person. The population used in the research was 16 farmers who raised eggs and conducted quantitative analysis such as cost, income, net profit, 
break-even point, net profit margin per cost, net profit margin per sales and return on investment (ROI).

\section{Findings}

The researcher collected data of 16 farmers who raised eggs which the results of the analysis can be shown as follows:

Table 2: Average cost of raising egg ducks per unit (Number of data collected 42,900).

\begin{tabular}{lll}
\hline \multicolumn{1}{c}{ Lists } & Amount (Baht per unit) \\
\hline Raw material cost & & 131.52 \\
Labor cost & Egg duck breed values & 131.52 \\
Production cost & Self labor cost & 67.13 \\
& & 67.13 \\
& Food cost & $1,410.63$ \\
& Vaccine / Supply & $1,377.80$ \\
& Feeding and water equipment & 1.43 \\
& Repair cost & 7.01 \\
& Depreciation & 21.58 \\
\hline
\end{tabular}

From Table 2, data analysis and cost structure of duck eggs found that the average total cost was $1,609.28$ baht per an egg duck, consisting of the average raw material cost 131.52 baht per an egg duck, 8.17 percent, average labor cost 67.13 baht per an egg duck, 4.17 percent and the average production cost is $1,410.63$ baht per an egg duck, equivalent to 87.66 percent.

Table 3: Profit (loss) from raising the average egg duck per unit.

Lists

Total income from raising an egg duck

Less cost of sales

Raw material cost

Labor cost

Production cost

Gross profit

Less operating expenses

Profit before deducting finance

costs

Less financial costs

Net profit
Amount (Baht per unit)
131.52

8.17

$1,410.63 \quad 1,609.28$

325.68

0

325.68

0

325.68

From Table 3, showing the results of the analysis of profits (losses) from the average egg production per unit, found that the average net profit per unit was 352.68 baht. 
Table 4: Cost categories for average break-even analysis per unit.

\begin{tabular}{llll}
\hline Variable cost & \multicolumn{3}{l}{ Fixed cost } \\
\hline Duck breed values & 131.52 & Feeding and water supplies & 2.01 \\
Food cost & $1,377.80$ & Repair cost & 7.81 \\
Vaccine / medical supplies & 1.43 & Depreciation & 21.58 \\
& & Self labor cost & 67.13 \\
\hline Total & $1,510.75$ & & 98.53 \\
\hline
\end{tabular}

From Table 4, showing the cost type for average break-even analysis per unit that found the average variable cost per unit was $1,510.75$ baht, average fixed cost per unit was 98.53 baht and the break-even point could be calculated from the following formula:

Break-even point $=\quad$ fixed cost per an egg

Selling price per bubble - Variable cost per bubble

$=\underline{98.53}$

$3.4-2.75$

152 eggs per unit

From calculating the break-even point, it was found that egg ducks would have to produce 152 eggs per unit to be cost-effective. Studying the return on investment in raising eggs focuses on the profit margin per cost, profit margin per sales, and return on investment as shown in Table 5.

Table 5: Calculating the return on investment of Laying Ducks per unit .

\begin{tabular}{lccc}
\hline Ratio & Formula (Per unit) & Calculate & Result \\
\hline Profit margin per cost & $\frac{\text { net profit } * 100}{\text { cost }}$ & $\frac{325.68}{1,609.28}$ & 20.24 \\
\hline \multirow{2}{*}{ Profit margin per sales } & $\frac{\text { net profit } * 100}{\text { sale }}$ & $\frac{325.68}{1,934.96}$ & 16.83 \\
\hline Return on investment & $\frac{\text { net profit * 100 }}{\text { investment }}$ & $\frac{325.68}{1,630.86}$ & 19.97 \\
\hline
\end{tabular}

From Table 5, shows the calculation of the rate of return from the investment in the average per unit which has a margin per cost of 20.24 percent, profit per sales ratio of 16.83 percent and a return on investment of 19.97 percent.

\section{Conclusion}

Raising egg ducks of farmers in Bang Pla Ma, Suphanburi Province, for 42,900 units which have the average cost of $1,609.28$ baht per unit, the average raw material cost of 131.52 baht per unit, or 8.17 percent, the average labor cost of 67.13 baht per unit or 4.17 percent and the 
average production cost of $1,410.63$ baht per unit or 87.66 percent, average net profit per unit of 325.68 baht, break-even point is 152 eggs per unit, margin per cost 20.24 percent, profit margin per sales 16.83 percent and rate of the return on investment of $19.97 \%$.

\section{Interpretation of the results}

The cost of raising egg ducks consists of 3 major parts: raw materials 8.17 percent, labor costs 4.17 percent and production costs 87.66 percent, indicating that the proportion of production costs is the highest which is in accordance with the research of Karnsuksa Medical and Faculty (2013) and Sangthian Chaemthong and Faculty (2017) caused by farmers raising egg ducks in the house will have the main cost of raising; ready-made food expenses and house building cost.

Returns for raising egg ducks with the average net profit of 325.68 baht per margin, net profit per cost ratio of 20.24 percent, profit per sales ratio of 16.83 percent and a return on investment of 19.97 percent, in line with Khun Pornporn Piepiyaphon and the faculty (2012). The breeding of house-type ducks has a net profit per an egg of $1.51 \pm 0.69$ baht / an egg and the net profit per cost is $3.35 \pm 23.87$ percent.

\section{Suggestions}

From the research, it was found that the cost of investment in raising egg duck is quite high when considering production costs, most of them are costs of food. Consequently, farmers may consider reducing food costs by using local raw materials that are cheap, such as rice bran, fine bran, bran, as a component of food.

\section{Suggestions of future research}

The researchers should study the cost and return from raising egg ducks by considering other methods which can compare the results to make the decision of investment for raising duck eggs.

\section{References}

Karnsuksupa, Chanya Kongrit, 2013. Study of raising and feeding conditions affecting duck egg quality Case study in Bang Len, Nakhon Pathom Province. Bangkok: National Research Council of Thailand.

Khun Pornporn Piyaphon and Faculty, 2565. Culture and duck production in Suphanburi, Ayutthaya and Nakhon Pathom. The 50th Kasetsart University academic conference (Nor. 171-178). Bangkok: Kasetsart University.

Chiraphon Ruangtaweesilp, 2014. Duck raising business. Searched on December 20, 2018, from https://www.Ihbank.co.th/Files/economic/economic_20161206154158.pdf

Songwit Charoenkitthanalap, 2017. Cost accounting. 4th edition. Saraburi: Conquer

Piyaraj Tejasub, 2014. Cost and return of investment. Non-toxic vegetable Kuicheai project for trade in Lampang province (self-study Master of Business Administration degree), Nation University. 
Varataya Somsamour, n.d. Egg duck ... duck eggs Valuable food, Bang Pla Ma, insist on raising. Searched on 21 December 2018, from https://www.technologychaoban.com/livestocktechnology/article_97581

Sasiwimol Miampon, 2007. Accounting for management. Type 9. Bangkok: Info Mining Company Limited. Sukjai Nowpanya, 2011. Costs and returns of rice cultivation among farmers, Moo 5, Hua Dong, Mueang District, Phichit Province. self-study Master of Business Administration. Rajamangala University of Technology Thanyaburi.

Sangthian Chaemthong and Faculty, 2017. Production status and attitude of raising Thung Thao Ducks in Phromphiram, Bang Krathum and Bang Rakam, Phisnu Lok province. Kaen Kaset, 45 (1).

Livestock Office, Suphan Buri Province. Statistical data. Search on 20 December 2018, from http://pvlospr.dld.go.th/webnew/index.php/en/service-menu

Jones, Kumen H., Werner, Michael L., Terrell, Katherne P., \& Terrell, Robert L, 2000. Contrasting financial and management accounting: New Jersey: Prentice Hall.

Maher, Michael W., Stickney, Clyde P., \& Well, Roman L, 2001.Managerial accounting.Boston:Harcourt 